\title{
SENI UKIR KHAS PALEMBANG PROVINSI SUMATERA SELATAN
}

\author{
Oleh: \\ Mainur \\ (Dosen FKIP Program Studi Pendidikan Sendratasik Universitas PGRI Palembang)
}

\begin{abstract}
Abstrak
Penelitian ini berisi tentang Seni Ukir khas Palembang Provinsi Sumatera Selatan. Penulisan ini bertujuan untuk mengembangkan dan memberikan wawasan serta informasi tentang ukiran khas Palembang. Dalam kajian Budaya Nusantara, ukiran khas Palembang ini tergolong ukiran yang keberadaannya sangat banyak diminati masyarakat di Daerah Sumatera Selatan khususnya kotamadya Palembang. Oleh karenanya Keberadaan ukiran khas Palembang di sini diurai secara ringkas dan dipaparkan secara Interaktif Kualitatif. Dari hasil analisis serta data observasi yang didapat dari seni ukir khas Palembang yaitu antara lain; Pemaparan mengenai Latar Belakang Seni Ukir Palembang, asal mula sejarah ukiran khas Palembang, dilanjutkan pemaparan tentang struktur mengenai sebuah Usaha Toko "Al-Ihsan" secara turun temurun, serta beberapa jenis motif ukiran khas Palembang.
\end{abstract}

Kata Kunci: Ukiran, Khas, Palembang 


\section{A. PENDAHULUAN}

Kotamadya Palembang merupakan ibu kota Provinsi Sumatera Selatan memiliki berbagai macam kesenian yang perlu mendapat perhatian secara terus-menerus, teratur dan terarah sesuai dengan perkembangan zaman dan kemajuan pembangunan, sehingga diharapkan dapat mewarnai dan memperkaya kesenian dan kebudayaan Indonesia. Kesenian daerah Palembang yang memiliki corak dan ragam dengan berbagai variasinya, merupakan kekayaan budaya bangsa yang tidak ternilai harganya, oleh karenanya perlu terus dibina dan dikembangkan.

Dalam usaha/upaya melestarikan seni ukir daerah baik yang masih berkembang maupun corak ukir yang hampir punah, seni ukir Palembang dan sekitarnya ini sebagai usaha penyebaran seni dan budaya daerah khususnya seni ukir untuk memperkaya khasanah kebudayaan Nasional.

Pada mulanya ukiran ini dikerjakan oleh para kaum wanita, dengan adanya perubahan dan perkembangan zaman sejak tahun 1832 pekerjaan tersebut kurang diminati oleh kaum wanita dan berangsur dilakukan oleh kaum pria, demikian laporan dari Controleur J.C. Banteburg yang memimpin utusan Palembang pada pameran seni ukir dalam rangka Kongres Java Institut diadakan di Kabupaten Bandung tahun 1921 (R.H.M Akib, Sejarah dan Kebudayaan Palembang1975). Mulai pada tahun 1921 seni ukir Palembang dikenal dimana-mana terutama dilihat dari gaya ukirannya sangat khas serta diberi warna keemasan (perada emas) di atas warna tepak (merah manggis).

Salah satu upaya untuk memelihara ciri khas/karakter daerah yaitu dengan mengadakan penelitian dan menyusun deskripsi kesenian dimaksud, di samping kesenian itu sendiri dapat diinventarisasi serta didokumentasikan sehingga dapat lebih mudah untuk membinna dan mengembangkannya.

Dari ungkapan dan pernyataan di atas ada beberapa alasan yang mendorong (Marah Adiel, 60 tahun) mengatakan:

"Alasan utama adalah untuk memperkenalkan salah satu dari keanekaragaman kesenian yang ada di Sumatera Selatan yaitu seni ukir Palembang dan sekitarnya. Seni ukir ini memiliki ciri khas lain dengan seni ukir daerah seperti; ukiran Jepara, ukiran Bali dan lain-lain. Ukiran Palembang mempunyai hubungan yang sangat erat dengan rumah adat Palembang (rumah bari) dengan corak ragam segala perlengkapannya, baik sebagai perhiasan rumah maupun dengan peralatan isi rumah adat itu sendiri". (Marah Adiel, 60 tahun. Wawancara 17 Juli 2014).

Secara geografis, Palembang terletak pada $2^{\circ} 59^{\prime} 27.99^{\prime \prime L S ~ 104 ² 5 ' 24.24 ~ L e t a k ~ " B T . ~ L u a s ~}$ wilayah Kota Palembang adalah 102,47 $\mathrm{Km}^{2}$ dengan ketinggian rata-rata 8 meter dari permukaan laut. Letak Palembang cukup strategis karena dilalui oleh jalan Lintas Sumatera yang menghubungkan antar daerah di Pulau Sumatera. Selain itu di Palembang juga terdapat sungai 
musi yang dilintasi jembatan Ampera dan berfungsi sebagai sarana transportasi dan perdagangan antar wilayah.

Kesenian dapat diartikan sebagai penghias kehidupan sehari-hari, yang dicapai dengan kemampuan tertentu sehingga memiliki estetika yang dapat digambarkan oleh masyarakat pendukungnya, serta mampu dijadikan sebuah manifestasi semua dorongan untuk mencapai keindahan. Oleh karena itu kesenian dapat meningkatkan kesenangan dalam segala tahap kehidupan (Herkovits, 1963: 235).

Kesenian tidak pernah lepas dari masyarakat sebagai salah satu unsur penting dalam kebudayaan, dan kesenian adalah ungkapan kreativitas (Kayam 1981: 38).

\section{B.METODE PENELITIAN}

Metode penelitian yang digunakan yakni deskriptif kualitatif, sehingga akan di deskripsikan sesuai dengan hasil analisis data yang telah tersaring yang didapat di lokasi penelitian. Metode deskriptif adalah suatu metode dalam pencarian fakta status kelompok manusia, suatu objek, suatu kondisi, suatu sistem pemikiran ataupun suatu peristiwa pada masa sekarang dengan interprestasi yang tepat (Sudarmayanti, dkk., 2002:33).

\section{C.PEMBAHASAN}

Kota Palembang ditinjau dari sudut pandang kerajinan ukirannya memang peninggalan warisan nenek moyang secara turun temurun. Adapun pusat produksi dan pemasaran yang ramai tepatnya terletak di kampung 19 ilir di samping Masjid Agung Palembang. Salah satunya yang diungkapkan oleh seorang pengusaha Ukiran Khas Palembang Toko "Al Ihsan".

Sehubungan adanya keterkaitan dengan usaha di atas ( $\mathrm{Hj}$. Bahusna, 98 tahun) mengatakan;

"sejak usia 12 tahun sudah mulai membantu orang tuanya yang menggeluti usaha ini. Hingga saat ini juga sudah diteruskan oleh anaknya ( $\mathrm{Hj}$. Badariah, 60 tahun), yaitu keturunan yang ke tiga, dengan penuh optimis alhamdulillah berjalan dengan lancar dan hasil sangat menjanjikan demi untuk kelangsungan hidup masa depan yang cerah tuturnya,..... Amin". (Hj. Bahusna, 98 tahun. Wawancara, 16 Juli 2014). 


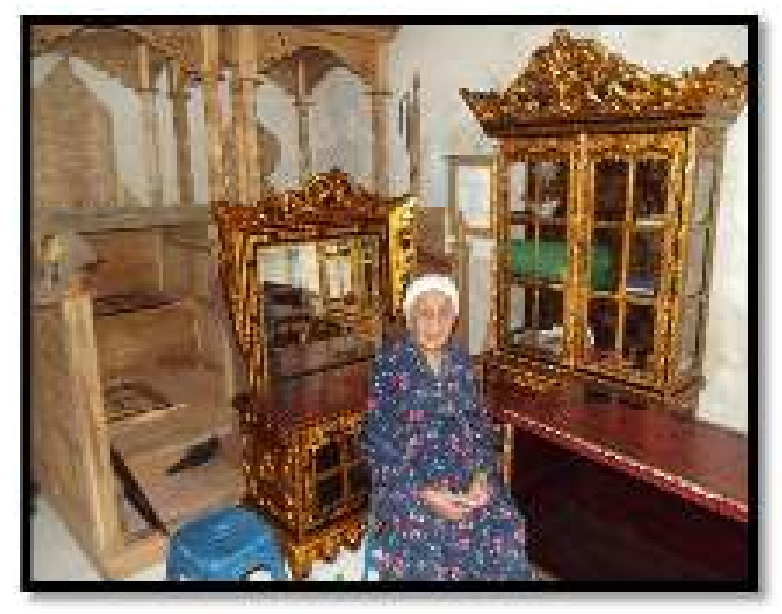

Gambar 1. Pemilik Toko "Al Ihsan" (Hj. Bahusna, 98 tahun)

Foto: Mainur 2014

Mengingat kembali sejarah Seni ukir Palembang memiliki motif khusus yang berbeda dengan daerah lain. Pengaruh Cina atau Budha masih menonjol, namun guratannya lebih didominasi tumbuhan, bunga melati dan teratai serta tidak ada gambaran tentang manusia atau hewan. Ciri ukiran Palembang sangat khas. Semua motifnya bunga dan pewarnanya pun di dominasi warna kuning keemasan, warna dominan dalam ukiran Palembang. Kemilau warna yang dihasilkan dari cat warna emas inilah yang membedakannya dengan ukiran daerah lain, seperti misalnya dari Jepara. Badan lemari, daun pintu, tutup Aquarium atau bingkai cermin dan foto, misalnya selalu disaput cat warna emas. Sementara bagian lainnya dilapisi warna merah tua dan hitam. Gambar bunga mawar dengan warna hitam makin menonjolkan penampilan ukiran kayu Palembang. Penerapan ukiran kayu Palembang banyak digunakan untuk ornamen bangunan rumah tradisional Palembang (rumah limas). Ada juga berbagai bentuk kerajinan ukiran khas Palembang seperti lemari hias berbagai ukuran, dipan, akuarium, bingkai foto dan cermin, kotak sirih, sofa, pembatas ruangan, dan sebagainya. Ukiran kayu Palembang (Sumatera Selatan) memiliki gaya, motif, dan warna yang khas. Kayu yang digunakan adalah kayu berkualitas, terutama kayu tembesu. Semua ukiran kayu Palembang bermotifkan bunga mawar dengan variasi cat warna emas, hitam, dan merah tua.

Pada perkembangannya lemari rek adalah semacam lemari pengantin dan ukurannya lebih besar, lemari pengantin tempatnya diletakkan di ruang induk rumah limas sekaligus sebagai pajangan menghiasi ruangan berisikan barang-barang yang disimpan dan dipajang di dalamnya seperti kain songket, keramik, dan lain sebagainya. Lemari rek ini mengalami beberapa perubahan, namun tidak terlepas dari unsur pokoknya yang disebut dengan lemari sudut khusus posisinya 
terletak di sudut ruangan yaitu pertemuan antara dua dinding ruangan. Lemari ini terdiri dari tiga sisi yaitu sisi kiri dan sisi kanan dan sisi depannya berbentuk melengkung

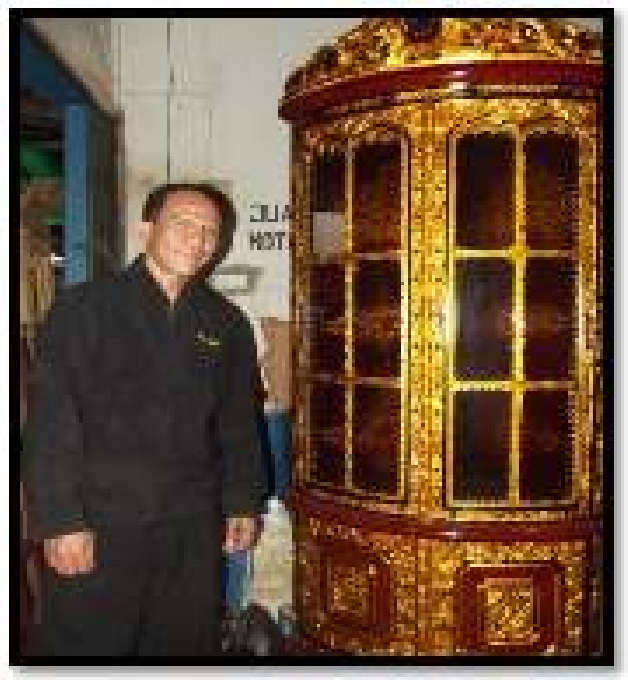

Gambar 2. Lemari Sudut Ruangan Tamu Ukiran Khas Palembang

(Foto: Mainur 2014)

Gaya ukiran Palembang adalah dekoratif dengan teknik rendah, tinggi dan tembus. Salah satu motif yang sering digunakan adalah Motif Bunga Mawar, sehubungan dengan motif bunga mawar ( $\mathrm{Hj}$. Badariah, 60 tahun), mengatakan bahwa

"Bunga Mawar adalah bunga beraroma harum dengan wangi memikat. Semerbak wanginya disukai siapa saja. Wangi bunga yang batang pohonnya berduri tersebut juga menjadi simbol dari rasa kasih dan cinta. Mungkin karena bunga dengan wangi khas ini adalah lambang yang tidak menggambarkan kekerasan, para pencetus kerajinan ukiran kayu Palembang menjadikannya sebagai motif utama. Semua ukiran kayu Palembang bermotifkan bunga mawar dengan variasi cat warna emas, hitam, dan merah tua". (Hj. Badariah, 60 tahun. Wawancara, 16 Juli 2014)

Berbagai bentuk kerajinan ukiran khas Palembang pun lahir dari tangan para perajin, seperti lemari hias berbagai ukuran, dipan, akuarium, bingkai foto dan cermin, kotak sirih, sofa, pembatas ruangan, dan sebagainya. Puluhan atau mungkin ratusan pengusaha kini menggantungkan hidup mereka dari kerajinan ukiran kayu Palembang. Ukiran kayu yang sejak beratus tahun tumbuh dan hidup di Palembang itu disukai banyak kalangan. Mengapa bunga mawar yang dipilih sebagai motif ukiran, baik perajin maupun pedagang, umumnya tidak tahu pasti. Mereka hanya mengerjakan dan mengetahui ukiran Palembang harus bermotifkan bunga mawar, baik yang tengah mekar, masih, kuncup, maupun daunnya. Saat ini, ukiran kayu khas Palembang telah tumbuh menjadi industri yang menjanjikan. Industri rumahan ukiran kayu Palembang tumbuh di 
banyak pelosok "Kota Pempek". Salah satu pusat perdagangan ukiran kayu Palembang terdapat di sejumlah jalan diantaranya Jl. Paqih Jalaluddin Kelurahan 19 llir di sekitar Masjid Agung Palembang.

Belasan ruang pamer (show room) yang sekaligus tempat mengecat atau mengerjakan tahap akhir ukiran (finishing touch) hasil karya para pengukir, terdapat di kawasan pusat kota. Ukiran pada benda pakai penerapan ukiran pada suatu benda supaya menambah keindahannya, atau untuk meningkatkan mutu bbenda pakai tersebut. Unsur keindahan atau aestetika pada seni ukir kayu menentukan keselarasan atau keharmonisan suatu benda yang pada akhirnya membentuk nilai artistik sebagai hasil budaya bangsa. Setiap daerah mempunyai bentuk, ragam dan gaya sendiri dalam menerapkan seni ukir daerahnya.

Dengan adanya ungkapan-ungkapan di atas maka ditarik kesimpulan bahwa, pengertian manajemen secara umum adalah suatu usaha yang terdapat di dalamnya suatu perencanaan, pengorganisasian, penerapan dan pengawasan atau evaluasi. Usaha ukiran Khas palembang Toko "Al Ihsan" ini cenderung menerapkan sistem manajemen yang bersifat sederhana. Sehingga penerapan manajemen yang profesional masih sangat jauh dengan yang diharapkan. Hal ini disebabkan karena keterbatasan sumber daya dan ketertutupan seorang pimpinan atau pemilik usaha Toko"Al Ihsan" ini. Oleh sebab itu dalam kesempatan ini akan dijelaskan pembahasan mengenai manajemen seni Ukiran Khas Palembang. Dalam penelitian kajian seni ukir khas Palembang ini merupakan fenomena kebudayaan yang terdapat di tengah masyarakat dengan menggunakan metode pendekatan emik dan etik dalam pengumpulan data yang dibutuhkan.

Dilihat dari sudut pandang secara umum, yang dimaksud dengan ukiran Palembang adalah ukiran kayu dengan gaya dan motif khas kedaerahan yang mempergunakan bahan kayu tembesu. Dari proses hingga penyelesainnya ukiran khas Palembang ini diberi warna merah, merah manggis (merah tepak), hitam, hijau, biru, kuning, dan warna perada keemasan.

\section{Usaha Toko "Al Ihsan" Ukiran Khas Palembang}

\section{A. Asal-usul Usaha Toko " Al lhsan" Ukiran Khas Palembang}

Usaha Toko "Al Ihsan" Ukiran Khas Palembang pada awalnya merupakan usaha sebuah keluarga dari lbu $\mathrm{Hj}$. Bahusna yang diwariskan oleh orang tuanya Bapak $\mathrm{H}$. Baharuddin/lbu $\mathrm{Hj}$.Hasuna keduanya (almarhum/almarhumah), keturunan asli daerah Kabupaten Ogan Komering ILir (OKI) Kayu agung, Provinsi Sumatera Selatan merantau ke Palembang dan membuka usaha ukiran khas Palembang dan menetap di kota pempek ini. 
Sehubungan adanya dengan keterkaitan usaha turun temurun keluarga tersebut, lebih lanjut (Ibu Hj. Badariah, 60 tahun) mengungkapkan;

"Sejalan dengan waktu dan zaman semakin berkembang dikenal oleh masyarakat di sekitarnya dan merambat jauh sampai ke pelosok daerah-daerah yang ada di Sumatera Selatan khususnya. Dari pertama kali tempat usaha ini dengan mengontrak sebuah rumah dan toko (Ruko) yang kebetulan ada di tengah pusat kota milik $\mathrm{H}$. Abdul Hasan dan hingga saat ini masih berjalan. Singkatnya pada saat ini dari tahun 2007 s.d 2014 sewa kontrakan ruko sebesar Rp. 40 juta / tahun". (Hj. Badariah, 60 tahun. Wawancara, 16 Juli 2014).

Usaha Toko "Al Ihsan" Ukiran Khas Palembang dalam pengolahannya di kerjakan oleh tangan-tangan terampil dan memiliki skill masing-masing dibidangnya seperti; pemilihan bahan baku menjadi bahan jadi, pinishing, pengecatan, dan pengeringan. Adapun bahan yang digunakan yaitu kayu tembesu, mahoni, dan Jati. Kerajinan ini sangat berkembang sesuai dengan keinginan dari konsumen dan mudah dijangkau baik dari transportasi darat maupun dari sungai atau laut yang menghubungkan kota Palembang dengan daerah-daerah lain yang ada di Sumatera Selatan.

Hampir di setiap rumah masyarakat Palembang ditemui beragam perabotan khas Palembang, dengan ukiran dan warna yang khas, maupun lemari rek. Lemari rek atau lakuer, hasil kerajinan yang sangat populer di Palembang. Seni ukir Palembang memiliki motif khusus yang berbeda dengan daerah lain. Pengaruh Cina atau Budha masih menonjol, namun guratannya lebih didominasi tumbuhan bunga melati dan teratai serta tak ada gambaran tentang manusia atau hewan. Ciri ukiran Palembang sangat khas, pewarnaannya pun di dominasi warna kuning keemasan, warna dominan dalam ukiran Palembang. Kemilau warna yang dihasilkan dari cat warna emas inilah yang membedakannya dengan ukiran daerah lain. Badan lemari, daun pintu, tutup aquarium atau bingkai cermin dan foto misalnya selalu disaput cat warna emas. Sementara bagian lainnya dilapisi warna merah tua dan hitam. Ukiran kayu palembang biasanya menggunakan jenis kayu tembesu yang keras dan kuat. 


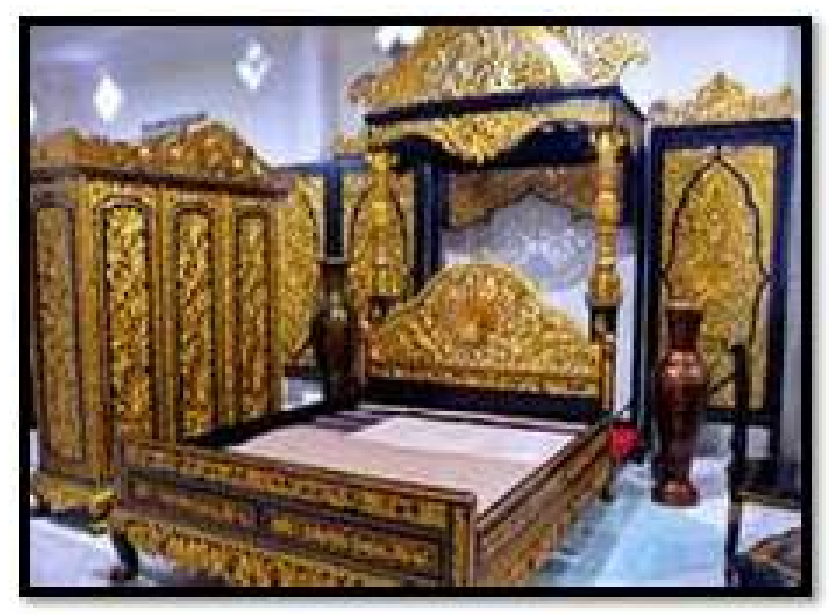

Gambar 3.

Singga Sana Ruang Kamar Tidur, Dipan \& Lemari Pakaian

Ukiran Khas Palembang

(Foto: Mainur, 16 Juli 2014)

Gaya ukiran Palembang umumnya menggunakan dekoratif dengan teknik rendah tinggi dan tembus (terawang) sedangkan motif seni ukiran yang umum digunakan tersebut dikenal dengan nama pohon kemalo.Penerapan ukiran kayu Palembang banyak digunakan untuk ornamen bangunan rumah tradisional Palembang (rumah limas). Ada juga berbagai bentuk kerajinan ukiran khas Palembang seperti lemari hias berbagai ukuran, dipan, akuarium, bingkai foto dan cermin, kotak sirih, sofa, pembatas ruangan dan sebagainya. Padahal dulu ukiran Palembang cuma terbatas pada lemari yang fungsinya untuk menyimpan kain songket.

Ukiran kayu yang sejak beratus tahun tumbuh dan hidup di Palembang itu disenangi banyak kalangan. Saat ini ukiran kayu khas Palembang telah tumbuh menjadi industri yang menjanjikan. Industri rumahan ukiran kayu Palembang tumbuh di banyak pelosok "kota pempek". Salah satunya pusat perdagangan ukiran kayu Palembang terdapat di sejumlah jalan di sekitar masjid Agung Palembang. Kawasan Jalan Faqih Jalaluddin 19 ilir Palembang ini merupakan tempat para perajin ukiran Palembang. Belasan ruang pamer show room ini sekaligus juga menjadi tempat mengecat atau mengerjakan tahap akhir ukiran (finishing touch) hasil karya para pengukir terdapat di kawasan pusat kota metropolis.

\section{Penduduk}

Penduduk Palembang merupakan etnis Melayu dan menggunakan Bahasa Melayu yang telah disesuaikan dengan dialek setempat yang kini dikenal sebagai Bahasa Palembang. Namun para pendatang seringkali menggunakan bahasa daerahnya sebagai bahasa sehari-hari, seperti 
bahasa Komering, Rawas, Musi llir, Musi Ulu, Pagaralam dan Lahat. Pendatang dari luar Sumatera Selatan kadang-kadang juga menggunakan bahasa daerahnya sebagai bahasa sehari-hari dalam keluarga atau komunitas kedaerahan. Namun untuk berkomunikasi dengan warga Palembang lain, penduduk umumnya menggunakan bahasa Palembang sebagai bahasa pengantar sehari-hari.

Selain penduduk asli, di Palembang terdapat pula warga pendatang dan warga keturunan, seperti dari Jawa, Minangkabau, Madura, Bugis dan Banjar. Warga keturunan yang banyak tinggal di Palembang adalah Tionghoa, Arab dan India. Kota Palembang memiliki beberapa wilayah yang menjadi ciri khas dari suatu komunitas seperti Kampung Kapitan yang merupakan wilayah Komunitas Tionghoa serta Kampung Al Munawwar, Kampung Assegaf, Kampung Al Habsyi, Kuto Batu, 19 llir Kampung Jamalullail dan Kampung Alawiyyin Sungai Bayas 10 llir yang merupakan wilayah Komunitas Arab. Agama mayoritas di Palembang adalah Islam. Di dalam catatan sejarahnya, Palembang pernah menerapkan undang-undang tertulis berlandaskan Syariat Islam, yang bersumber dari kitab Simbur Cahaya. Selain itu terdapat pula penganut Katolik, Protestan, Hindu, Buddha dan Konghucu.

\section{B. Sistem Manajemen Seni Usaha Toko "Al Ihsan" Ukiran Khas Palembang}

Secara umum pengertian dari Manajemen adalah suatu usaha dimana di dalamnya terdapat perencanaan, pengorganisasian, penerapan, dan pengawasan atau evaluasi. Pada Usaha Toko "Al IHSAN" Ukiran Khas Palembang menggunakan bentuk manajemen yang sifatnya sangat sederhana yang dikelola oleh keluarga ( $\mathrm{Hj}$. Badariah, 60 tahun) sebagai berikut :

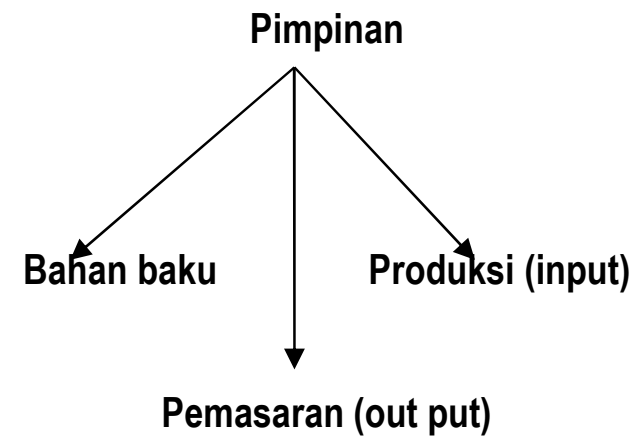

Dari keterangan diagram di atas bahwa sistem manajemen dikelola oleh keluarga, sebagai peran pemilik usaha menentukan segalanya terutama pada aspek pemilihan bahan baku/bahan setengah jadi, produksi (input), dan pemasaran (out put). Sifat manajemen ini masih sangat jauh untuk dikatakan profesional dan sangat sederhana sekali dalam menggunakan manajemen keluarga dengan cara turun temurun. 


\section{Manajemen Produksi \\ a. Modal Usaha}

Berawal dari Usaha kerajinan Ukiran Khas palembang ini, sudah pasti membutuhkan modal. Modal usaha yang digunakan jelas untuk menunjang sarana dan prasarana proses produksi. Lebih kurang 15 tahun yang lalu setelah usaha diturunkan sama lbu $\mathrm{Hj}$. Badariah, (60 tahun), (turun temurun ke-3) mengungkapkan:

"Pinjaman dana bantuan dari Bank Sumsel di samping modal keluarga sendiri untuk kelangsungan usaha tersebut. Dana yang dapat dicairkan oleh Bank Sumsel sebesar Rp. 75.000.000,- dan modal pribadi keluarga sebesar Rp. 80.000.000,-. Alhamdulillah dana dari Bank Sumsel sudah selesai dilunasi dalam jangka 4 tahun berikutnya dan sampai saat ini menggunakan dana produksi dengan modal usaha keluarga tanpa dana dari pihak lain. Hanya sewa ruko saja setiap tahunnya harus dibayar sebesar Rp 40.000.000,-/tahun. Usaha ukiran khas palembang ini mencoba membuka cabang di tempat lain masih dijantung kota pempek daerah Sayangan14 llir, sewa ruko masih tergolong murah berkisar antara $R p 20.000 .000$,- s.d Rp 25.000.000,tetapi hanya bertahan dalam jangka 2 tahun tidak mendapatkan keuntungan bahkan penghasilan mines pada tahun keduanya dan diputuskan untuk ditutup. $(\mathrm{Hj}$. Badariah, 60 tahun. Wawancara 16 Juli 2014).

\section{b. Tenaga Kerja}

Usaha Toko "AL IHSAN" Ukiran Khas Palembang ini menggunakan manajemen produksi dengan bahan utama/bahan baku atau bahan setengah jadi langsung beli pada langganan rutin setiap pemesanan bahan sesuai aturan yang disepakati bersama. Artinya dalam hal ini Usaha Toko "AL IHSAN" Ukiran Khas Palembang tidak memiliki lahan untuk persediaan bahan baku. Tenaga kerja bersifat tetap (tenaga ahli pengukiran), dan tenaga lepas/harian (tenaga finishing, amplas, pengecatan). Untuk tenaga tetap mengerjakan proses produksi pola dan motif ukiran yang akan diproduksi sesuai dengan pesanan konsumen disamping untuk dipajangkan di pamer dalam toko. Tenaga tetap ini mendat upah yang diterima per minggunya sebesar Rp. 500.000,- s.d Rp. 600.000 ,- sedangkan tenaga tidak tetap (harian lepas) menerima upah sebesar Rp 30.000,- s.d Rp 35.000,- / harinnya sesuai hasil pekerjaan masing-masing, dengan jumlah tenaga 4 Orang (wawancara dengan Abdul Rozak, 26 tahun, seorang perajin Toko "AL IHSAN) Ukiran Khas Palembang).

\section{c. Proses produksi}

Untuk memproduksi usaha ukiran khas Palembang dan menghasilkan produk ukiran yang memiliki nilai estetis / keindahan, maka ada beberapa tahap pengerjaan dengan hasil maksimum. Menurut Monroe Beardsley dalam proses kereatifitas (dalam Dharsono, 2007:63) menjelaskan tiga 
ciri menjadi sifat membuat baik (indah) dari benda-benda estetis. Ketiga ciri tersebut yaitu kesatuan (unity), kerumitan (complexcity), kesungguhan (intensity).

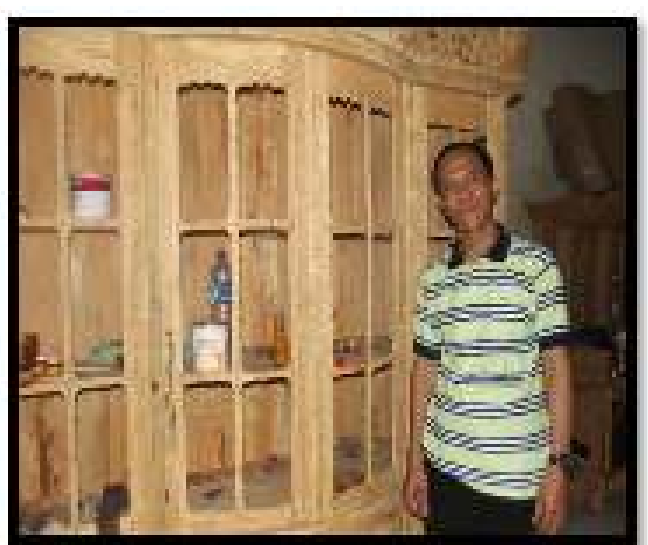

Gamabar 4. Proses Lemari Ukir Khas Palembang dari bahan setengah jadi (Foto: Mainur, 16 Juli 2014)

\section{d. Pemasaran Produk}

Ditinjau dari pandangan secara umum usaha Toko " AL IHSAN "Ukiran Khas Palembang dipasarkan sesuai dengan pesanan konsumen dan langsung antar di tempat. Adapun jenis produk yang di pesan yaitu; lemari rek, bupet tiga pintu, dipan, kaca hias, dan kursi, semuanya ukiran khas Palembang. Pesanan konsumen banyak berasal dari daerah Bandung, Jakarta, Lampung, Jambi dan Pekan Baru dan tidak sedikit juga berasal dari luar daerah kota Palembang seperti derah OKU Timur, Ogan Komering llir (OKI), Sekayu, Musi Banyuasin, Sungai Lilin, Lahat, Muara Enim, Prabu Mulih dan juga daerah lainnya.

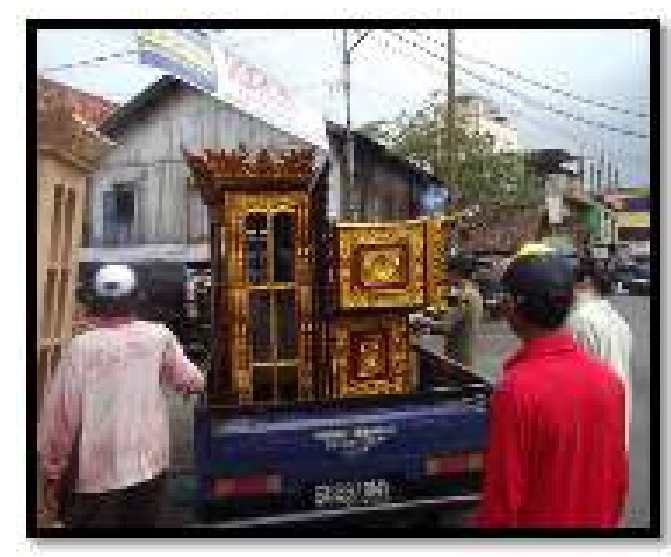

Gambar 5. Pengirimam barang pesanan konsumen (Foto: Mainur, 16 Juli 2014)

Pada awal berdirinya usaha Toko " AL IHSAN " Ukiran Khas Palembang adalah satusatunya yang terdapat di Jl. Paqih Jalaluddin Kelurahan 19 llir Palembang. Dari tahun ke tahun daerah seputaran Masjid Agung semakin bertambah banyak dengan berdiri gedung ruko yang dipadati oleh usaha ukiran khas Palembang, sekarang mencapai 20-an ruko. 


\section{e. Jumlah Produk}

Berdasarkan data yang ada dalam proses pembuatan ukiran khas Palembang tergantung besar atau kecilnya ukiran yang dibuat. Misalnya lemari pakaian empat pintu, dari proses produksi makan waktu lebih kurang empat sampai lima hari, dan yang paling kacil seperti bupet TV, meja hias, membutuhkan waktu lebih kurang dua hari sampai dengan pengecatan.

Sehubungan dengan proses produksi ukiran khas Palembang di Usaha Toko "Al-Ihsan" Palembang, ( Ahmad Jauhari, 38 tahun perajin dan pemasaran), berdasarkan pengalaman mengatakan;

"Dengan jumlah empat orang tenaga ahli perajin ukiran khas Palembang maka penghitungan per bulannya jumlah produk yang dihasilkan lebih kurang sebanyak enam sampai dengan tujuh jenis ukiran yang corak berbeda-beda bentuknya, dan kesemuanya siap untuk diantar sampai di tempat sesuai dengan pesanan konsumen". (Ahmad Jauhari, 38 tahun. Wawancara 16 Juli 2014).

Tetapi jika pesanan dari konsumen meningkat maka Ibu Hj. Badariah, (60) menambah tenaga ahli tambahan dengan sistem borongan dengan syarat mutu kualitas produk tetap diutamakan supaya tidak mengecewakan pelanggan/konsumen. Hal ini biasanya terjadi peningkatan kuota permintaan konsumen pada waktu bulan ramadhan atau biasanya musim merit/penganten. Harga untuk ukiran khas Palembang pada usaha Toko " AL IHSAN " masing-masing dijelaskan seperti pada tabel di bawah ini ;

Daftar harga Usaha Toko Al'Ihsan" Ukiran khas Palembang tahun 2014 Jl. Paqih Jalaluddin Kelurahan 19 llir Palembang.

\begin{tabular}{|c|c|c|c|}
\hline Nama Barang & Harga & Nama Barang & Harga \\
\hline Lemari Rek & Rp 9.000 .000 & Wadah Pengasan & Rp. 2.750.000 \\
\hline Lemari Pakaian & Rp 14.000 .000 & Dipan / Sofa & Rp. 8.500.000 \\
\hline Meja Hias & Rp. 4,500,000 & $\begin{array}{c}\text { Lemari Sudut } \\
\text { (Pojok) }\end{array}$ & Rp. 7.500.000 \\
\hline Meja Tamu & Rp. $5.500,000$ & Kursi Singga Sana & Rp.12.500.000 \\
\hline Bupet TV & Rp. 4.500 .000 & Dinding Pembatas & Rp. 7.000.000 \\
\hline
\end{tabular}

Sumber: Usaha Toko Al'Ihsan" Ukiran khas Palembang tahun 2014.

Berdasarkan ungkapan pokok bahasan dan temuan di atas dapat di pahami tentang sistem manajemen seni yang digunakan oleh pengrajin Usaha Toko " AL IHSAN " Ukiran Khas Palembang. Dengan keterkaitan usaha tersebut ada tiga hal penting pada bentuk manajemen usaha keluarga, 
proses pembuatan, dan pemasaran produk sebagai temuan yang sesuai dengan permasalahan pada penelitian ini adalah sebagai beriku :

Proses pembuatan telah dijelaskan di atas bahwa tanpa adanya sarana dan prasarana, terutama modal, bahan baku, tenaga ahli, semuanya harus lengkap karena semua ini terdapat kaitan yang sangat erat. Jika salah satu diantaranya tidak ada maka kelangsungan proses produksi akan mengalami hambatan dan timbul sebuah fenomena, jelas berpengaruh dalam hitungan rugi laba pada manajemen seni yang dipakai.

Usaha keluarga ini bersifat tradisional serta turun temurun dari keluarga, seperti yang dijalankan oleh lbu $\mathrm{Hj}$. Badariah, (60). Hingga saat ini masih eksis dan berjalan tanpa adanya hambatan baik dari segi modal maupun bahan baku termasuk karyawan (tenaga ahli) diantara mereka ada yang sampai belasan tahun jadi pengrajin ukiran yang mereka geluti bersama pimpinannya $\mathrm{Hj}$. Badariah. Dengan adanya keadilan dan kebijaksanaan ibu $\mathrm{Hj}$. Badariah, (60), itulah yang membuat pengrajinnya semakin betah dan saling menguntungkan satu dengan yang lainnya.

Berdasarkan pemaparan dan dampak yang akan muncul sebagaimana dari ungkapan dan pernyataan di atas maka disampaikan saran sebagai berikut:

1. Kerajinan ini sangat baik untuk dikembangkan lebih jauh lagi. Hingga kini penjualan masih terbatas di kota Palembang atau di luar kota Palembang, belum menjangkau luar negeri.

2. Sangat menguntungkan sekali baik bagi masyarakat konsumennya maupun pengrajin jika kerajinan khas Palembang ini bisa diekspor, selain bisa meningkatkan perekonomian para perajin tentu juga menambah pemasukan pendapatan asli daerah.

3. Para perajin umumnya mengeluhkan dana dan birokrasi pengiriman barang ke luar negeri. Untuk itulah dibutuhkan pendampingan secara menyeluruh dari Pemerintah.

4. Sinergi yang terjalin antara perajin, investor dan Pemerintah akan memberikan kekuatan untuk menembus pasar dunia. Bukan tak mungkin kerajinan yang umumnya berada di rumah masyarakat Palembang ini bisa juga menjadi penghias dan pelengkap perabotan para masyarakat di belahan dunia lain.

\section{D.SIMPULAN}

Seni ukir Palembang sebagai salah satu tangkai kesenian yang ada di Palembang telah ditemukan sejak zaman dahulu dan dapat bertahan serta berkembang hingga sekarang. Perkembangannya mengalami pasang surut, pernah mengalami masa jayanya dan pernah juga mengalami kemerosotonnya, sehingga tinggal beberapa orang saja selaku pengrajinnya. Melalui 
berbagai upaya kini seni ukir Palembang bangkit kembali dan dapat merebut pasaran di berbagai kota besar di Indonesia dan manca Negara.

Upaya pengembangan seni ukir Palembang perlu diteruskan oleh instansi pemerintah maupun oleh badan-badan swasta seperti Dekranas, koperasi, sanggar dan lain sebagainya. Selain dari pada itu yang tidak kalah pentingnya adalah dukungan bahan baku. Hutan sebagai penunjang bahan baku ukiran kayu terutama ukiran kayu tembesu perlu pemikiran tentang peremajaan dan pembudidayaan.

\section{DAFTAR PUSTAKA}

Guntur, Studi Ornamen Sebuah Pengantar (Surakarta: P2AI bekerja sama dengan STSI Press Surakarta, 2004).

Moeslih dan Sudarmono, Penuntun Praktek Kerajinan Ukir Kayu, Departemen Pendidikan dan Kebudayaan, Jakarta 1984.

R.H.M. Akib, Sejarah dan Kebudayaan Palembang, Rumah adat Limas, Palembang.

Shdily, Hasan.1982. Ensiklopedia Indonesia, Jakarta : Ichtiar Baru-Van Hoeve.

Sony Kartika, Dharsono ,2000. Estetika. Bandung: Rekayasa Sains. ,2007. Estetika, Bandung: Rekayasa Sain. 